\title{
Group A Streptococcal Pericarditis in a Four-Month-Old Infant Case report
}

"Badria R. Al-Waili, ${ }^{1}$ Sunny K. Zacharias, ${ }^{2}$ Emad Aslem ${ }^{3}$

$$
\text { التهاب غشاء التامور بالميكروب العقدي النوع أ في طفل عمره } 4 \text { أشهر }
$$$$
\text { بدرية راشد الوائلي، صني زكرياس، عماد أسلم }
$$

ABSTRACT: Purulent pericarditis is uncommon among paediatric patients and cases caused by group A Streptococcus (GAS) are even rarer. We report a four-month-old female infant who was referred to the Royal Hospital, Muscat, Oman, in 2015 with pericardial effusion and cardiac tamponade. She had initially presented to a secondary hospital with a two-week history of fever, a runny nose and shortness of breath. Blood and pericardial fluid cultures confirmed GAS isolates. The infant was treated with a two-week course of antibiotics and made a complete recovery with no echocardiographical evidence of pericardial effusion at a two-month follow-up. To the best of the authors' knowledge, this case constitutes the youngest infant to present with GAS pericarditis. As invasive GAS infections can present in infancy, early recognition and treatment is required.

Keywords: Infant; Pericarditis; Pericardial Effusion; Streptococcus Group A; Case Report; Oman.

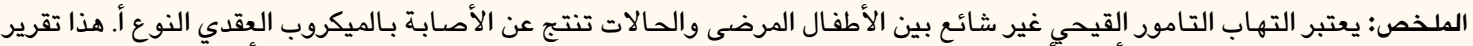

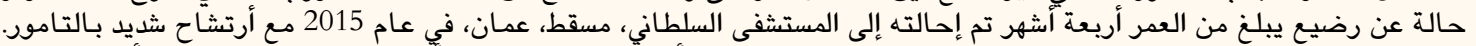

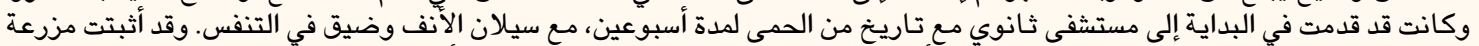

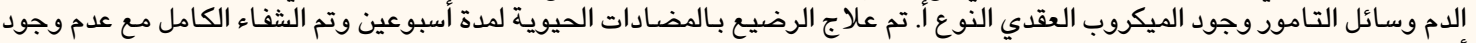

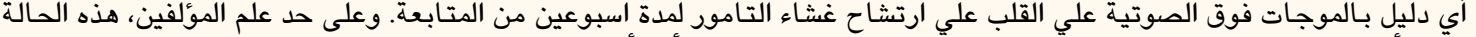

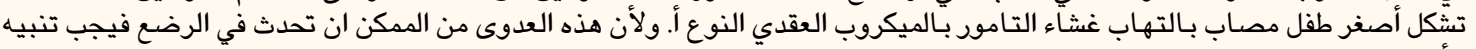
الأطباء الي ضرورة التعرف المبكر عليها وعلاجها.

$$
\text { الكلمات المفتاحية: الرضع؛ التهاب التامور؛ ارتشاح التامور؛ الميكروب العقدي النوع أ؛ تقرير حالة؛ عمان. }
$$

A LSO KNOWN AS GROUP A STREPTOCOCCUS (GAS), Streptococcus pyogenes is a genus of $\beta$ haemolytic bacteria belonging to serogroup A according to the Lancefield grouping classifications. ${ }^{1}$ It is an extremely common human pathogen which can cause a variety of clinical diseases ranging from superficial to invasive and including toxin-mediated infections as well as post-infection sequelae. ${ }^{2,3}$ Invasive GAS disease is defined as an infection in which GAS is isolated from a sterile site of the body. ${ }^{2}$ Approximately $90 \%$ of all pericarditis infections are either viral or idiopathic in origin. ${ }^{3}$

Purulent pericarditis is defined as an infection of the pericardium that produces pus often found via gross examination of the pericardial sac or tissue microscopy; it commonly develops secondarily to a primary bacterial infection at an alternate location, such as pneumonia. ${ }^{3}$ The pericardium is subsequently infected by septic emboli, or a direct spread of infection from the lungs., ${ }^{4,5}$ Most of the identified bacterial isolates in cases of paediatric pericarditis are Staphylococcus aureus or Streptococcus pneumoniae. ${ }^{5,6}$ In contrast, GAS is a rare cause of purulent pericarditis, with only nine paediatric cases reported to date. $^{7-13}$

\section{Case Report}

A four-month-old female infant was referred to the Royal Hospital, Muscat, Oman, in 2015. She had initially presented to a secondary hospital in Muscat with a two-week history of fever, a runny nose and shortness of breath. She had no history of medical problems and had had a normal birth. Upon initial presentation, she was afebrile and in marked respiratory distress with subcostal and intercostal muscle recession as well as desaturation. Her respiratory rate was 40 breaths/ minute and her heart rate was 100 beats/minute. Oxygen saturation was $98 \%$ with $2 \mathrm{~L}$ of oxygen. 


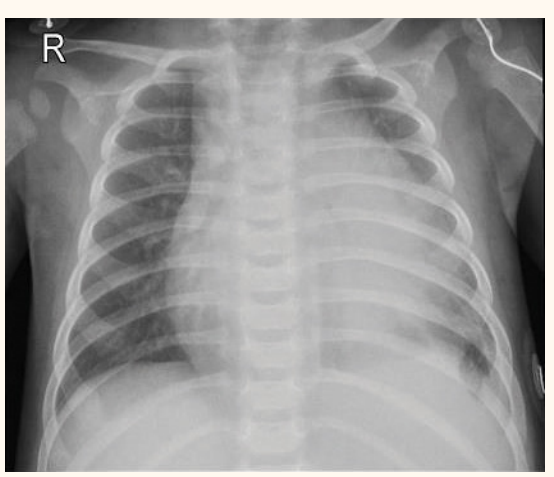

Figure 1: Chest X-ray of a four-month-old female infant with pericardial effusion and cardiac tamponade showing cardiomegaly and a normal lung field.

A chest examination showed good air entry with no abnormal sounds. Normal heart sounds were heard during a cardiovascular examination. An abdominal examination revealed hepatomegaly with the liver located $7 \mathrm{~cm}$ below the costal margin. A chest X-ray showed evidence of cardiomegaly, although the lungs appeared normal [Figure 1]. Echocardiography performed by a paediatrician at the secondary hospital revealed pericardial effusion with cardiac tamponade. A total of $30 \mathrm{~mL}$ of pus was drained via needle aspiration and sent for microscopy and cultures. Ceftriaxone and vancomycin were prescribed for 48 hours before the infant was transferred to the Royal Hospital, a tertiary hospital, for evaluation by a cardiologist.

Upon referral, repeated echocardiography revealed pericardial effusion with $14 \mathrm{~mm}$ of fibrotic tissue on the right side of the left ventricle and $7 \mathrm{~mm}$ of fibrotic tissue at the apex, with diastolic compression of the right atrium. A pericardial drain was inserted to remove $100 \mathrm{~mL}$ of serous fluid. Fibrous material was present in the pericardial cavity but was washed out before the drain was inserted. Blood investigations revealed a haemoglobin level of $8.5 \mathrm{~g} / \mathrm{dL}$, white cell count of $49 \times 10^{9}$, platelet count of 773, neutrophil count of $29.9 \times 10^{9}$, lymphocyte count of $7.9 \times 10^{9}$, lactate dehydrogenase level of $561 \mathrm{U} / \mathrm{mg}$ and thyroxine stimulating hormone level of $4 \mathrm{IU} / \mathrm{L}$. A respiratory viral panel was positive for rhinovirus. Fluid protein and glucose levels were $52 \mathrm{~g} / \mathrm{L}$ and $<0.3 \mathrm{mmol} / \mathrm{L}$, respectively. Microscopic tests of the pericardial pus indicated no evidence of organisms with moderate polymorphs. However, her fluid and blood cultures were positive for GAS. The patient was prescribed a two-week course of penicillin and made a complete recovery. At six months old, follow-up echocardiography revealed no pericardial effusion with normal cardiac structure and no valve regurgitation.

\section{Discussion}

Among paediatric patients, the most common bacteria causing purulent pericarditis are S. aureus, S. pneumonia and Haemophilus influenza., ${ }^{5,9}$ In contrast, purulent paediatric pericarditis originating from a GAS infection is rare; a review of the literature identified only nine cases, with patients ranging in age from 10 months to 14 years old. ${ }^{7-13}$ Accordingly, to the best of the authors' knowledge, the current case constitutes the youngest infant reported so far to present with GAS pericarditis. Of the previously reported cases in which gender was identified, five patients were male and four were female. ${ }^{5-7,14}$ For four patients, the source of the GAS was identified as both pharyngitis and cellulitis, pharyngitis alone, pneumonia alone and both pharyngitis and bacteraemia. ${ }^{6,8}$

Schwartz et al. reported a 10-month-old infant whose father had been diagnosed with GAS pharyngitis; the infant presented with prolonged fever and purulent pericarditis with no identifiable primary focus. ${ }^{7}$ In contrast, the patient in the current case was a four-month-old infant who presented with a rhinovirus infection, which may potentially have been the source of a secondary bacterial infection and bacteraemia. She presented with a history of fever and the initial delay in prescribing antibiotics could have led to the development GAS bacteraemia and purulent pericarditis. Acute respiratory distress is a common presentation in paediatric emergencies and is usually caused by acute bronchiolitis. ${ }^{8}$ However, in the present case, a chest X-ray revealed cardiomegaly, consequently raising concerns of the possibility of pericarditis or myocarditis. Although acute pericarditis is predominantly viral in origin, GAS was not suspected as it is not a common pathogen in this age group. ${ }^{3,6}$ Nevertheless, blood and pericardial fluid cultures confirmed the diagnosis of GAS pericarditis.

Systemic antibiotics and pericardial drainage are required to treat purulent pericarditis. ${ }^{5}$ While there is as yet no agreed upon duration for courses of antibiotics for the treatment of purulent pericarditis, most cases with successful outcomes are treated for 2-4 weeks. ${ }^{6,9}$ In the current case, the patient received two weeks of antibiotics with adequate pericardial drainage, which resulted in a complete recovery. Unfortunately, the mortality rate for children with bacterial pericarditis ranges from 5-12\%, even with treatment. ${ }^{6,79,14}$ 


\section{Conclusion}

To the best of the authors' knowledge, this case describes the youngest infant to present with GAS pericarditis to date. As it is possible for GAS pericarditis to present in early infancy, physicians should be aware of this rare yet treatable condition in order to prevent poor or potentially fatal outcomes.

\section{References}

1. Lancefield RC. A serological differentiation of human and other groups of hemolytic Streptococci. J Exp Med 1933; 57:571-95. doi: $10.1084 /$ jem.57.4.571.

2. Curtis N. Invasive group A Streptococcal infection. Curr Opin Infect Dis 1996; 9:191-202. doi: 10.1097/00001432-19960600000012 .

3. Shiber JR. Purulent pericarditis: Acute infections and chronic complications. Hosp Physician 2008; 45:9-17.

4. Lange RA, Hillis LD. Clinical practice: Acute pericarditis. N Eng Med 2004; 351:2195-202. doi: 10.1056/NEJMcp041997.

5. Gersony WM, McCracken GH Jr. Purulent pericarditis in infancy. Pediatrics 1967; 40:224-32.

6. Roodpeyma S, Sadeghian N. Acute pericarditis in childhood A 10-year experience. Pediatr Cardiol 2000; 21:363-7. doi: $10.1007 / \mathrm{s} 002460010081$.
7. Schwartz MC, Gillespie MJ, Stephens P Jr, Fisher B. Cardiac tamponade due to group A streptococcal pericarditis in a 10-month-old boy and a review of the literature. Open J Pediatr 2011; 1:87-9. doi: 10.4236/ojped.2011.14020.

8. Angoulvant F, Bellanger H, Magnier S, Bidet P, Saizou C, Dauger S. Acute purulent pericarditis in childhood: Don't forget $\beta$-haemolytic group-A Streptococcus. Intensive Care Med 2011; 37:1709-10. doi: 10.1007/s00134-011-2259-4.

9. Bhaduri-McIntosh S, Prasad M, Moltedo J, Vázquez M. Purulent pericarditis caused by group A Streptococcus. Tex Heart Inst J 2006; 33:519-22.

10. Gersony WM, McCracken GH Jr. Purulent pericarditis in infancy. Pediatrics 1967; 40:224-32.

11. Pruitt JL. Group A streptococcal pericarditis in a previously well child. Pediatr Infect Dis J 1989; 8:338.

12. Thébaud B, Sidi D, Kachaner J. [Purulent pericarditis in children: A 15 year-experience]. Arch Pediatr 1996; 3:1084-90. doi: 10.1016/S0929-693X(96)89513-3.

13. Vigneswaran WT, Hardie R, Ferguson JC, Faichney A. Cardiac tamponade due to Lancefield group A beta haemolytic streptococcal pericarditis. Thorax 1985; 40:549-50. doi: 10.11 36/thx.40.7.549

14. Cakir O, Gurkan F, Balci AE, Eren N, Dikici B. Purulent pericarditis in childhood: Ten years of experience. J Pediatr Surg 2002; 37:1404-8. doi: 10.1053/jpsu.2002.35401. 